Article

\title{
Agritourism: A Hedonic Approach of Quality Tourism Indicators in South Tyrol
}

\author{
Katia Laura Sidali ${ }^{1, *}$, Anna Spitaler ${ }^{2}$ and Günter Schamel ${ }^{2}$ (D) \\ 1 Department of Business Economics, University of Verona, Via Cantarane, 24 1, 37129 Verona, Italy \\ 2 Faculty of Economics and Management, Free University of Bozen-Bolzano, Piazza Università 1, \\ 39100 Bozen, Italy \\ * Correspondence: katialaura.sidali@univr.it; Tel.: +39-0458028592
}

Received: 23 May 2019; Accepted: 4 July 2019; Published: 9 July 2019

\begin{abstract}
This paper examines the prices of agritourism accommodation that include food services (i.e., the option to have breakfast) and related farm attributes. We analyze what tourists are willing to pay per night for a designated farm holiday stay in South Tyrol offered through the "Red Rooster" brand $(n=367)$. We first identify factors that may influence tourist decisions to book a holiday at a farm, which include the number of flowers (i.e., the red rooster quality-rating scheme), the type of accommodation, the distance to various leisure activities, and externalities related to agricultural practices. Second, the paper develops two hedonic models to estimate implicit prices for farm holiday accommodation rates. Specifically, the dependent variables are the prices paid by guests during the summer peak and low seasons. Independent variables are various accommodation attributes, the quality of food service, and the range of possible activities in the area surrounding the farm. The results of the study show that the red rooster quality-rating scheme (i.e., the number of flowers) and the quality of food services are highly significant and have a positive impact on guest willingness to pay. Farm types, such as fruit-growing and livestock operations, have a significant but negative effect on accommodation rates at least during the peak season, whilst wine production and organic farming display a positive influence on the accommodation rates during the low season. Implications for practitioners and policy-makers are discussed.
\end{abstract}

Keywords: farm tourism; sustainable tourism; South Tyrol; hedonic pricing model approach; regression

\section{Introduction}

In rural economies, diversification towards non-farming activities is a key factor among rural development policies [1-3]. Above all, tourism is recognized as a tool to increase the income of farmers and employment opportunities in rural regions [4,5]. For these reasons, the European Union has invested, since 2000, in the promotion of agritourism or farm tourism in the frame of the second pillar of the CAP (common agricultural policy) to boost rural development.

From a managerial viewpoint, it is worth highlighting that, contrary to other forms of tourism, agritourism operators face the challenge of efficiently allocating all their farming activities without decreasing the attractiveness of the farm setting in the eyes of tourists. The linkage between farming activities and farm holidays merits a deep understanding of the fragile balance between agriculture and tourism. From the one hand, the farmer's gaze is directed to a context of decreasing agricultural subsidies that have pushed farmers to increase investments towards cash crop and intensive husbandry. On the other hand, the "tourist gaze" [6] is turned on a very dynamic context. As shown by anecdotal literature, the increased digital literacy and environmental awareness are empowering tourists who choose their holiday destination very critically to the extent that they may potentially boycott destinations that are not in line with their set of values or are not considered authentic (see 
https://www.telegraph.co.uk/news/2017/08/14/tourists-boycott-dolomites-brown-bear-killed/ accessed February 2019). Specifically, in the context of tourism in rural areas, scholars have shown that the encounter with a mechanized agriculture often frustrate tourists' expectations of an unspoiled and idealized nature.

Hence, the purpose of this study is to enhance clarity on the contribution of farming activities on the attractiveness of the rural tourism sector. In the remainder of the paper, we introduce a literature review on the theory of agricultural externalities and their linkages with tourism, followed by a case study, namely the Italian region of South Tyrol. We present a hedonic pricing approach used to detect to what extent the type of activities offered by farm operators in the studied region influences prices of tourist accommodations. Finally, results are discussed and some recommendations for both scholars and practitioners are presented.

\section{Literature Review}

Agriculture produces both positive and negative consequences, which in the economic literature are called externalities. The EU legislator have tackled the problem of negative externalities such as nitrate pollution or intensive animal husbandry passing from a coercive approach to a more proactive one-i.e., the paid stewardship — which focuses on the farmers' provision of payments for reducing the use of harmful inputs such as pesticides [7]. Furthermore, with the implementation of the Agenda 2000 and the financial reinforcement of the second pillar of the CAP devoted to the rural development, the EU legislator explicitly endorses the positive externalities of agriculture, which, according to Howley et al. [7], can be divided into environmental public goods (such as a scenic landscape) and social externalities related to agriculture (such as animal welfare).

A combination of factors such as increasing environmental awareness, the search for quality of life, and the availability of more time for leisure, have led to a constant increase of the marginal value of agricultural positive externalities. For instance, Waltert and Schläpfer [8] and Judson et al. [9] showed the potential of agricultural positive externalities such as landscape amenities, to attract immigrants to rural areas even at the cost of a lower wage. On the same line, Beyers and Lindahl [10] demonstrated the potential of natural resources to attract entrepreneurs to rural areas at the expense of higher profits. In the case of tourism in rural areas, to which agritourism belongs, a multiplicity of studies seems to indicate that natural resources linked to agriculture may provide a basis for recreational and outdoor businesses [11,12]. However, it lacks consensus on which agricultural externalities satisfy the demand for rural tourism and, more specifically, for agritourism.

For instance, van Huylenbroeck et al. [12] showed that intensive agriculture and livestock farming may be detrimental for agritourism, whilst Sidali [13] detected positive effects of the vineyard farming on rental prices of agritourism operations. Also, the magnitude of the intrinsic values of positive externalities of agriculture on final prices is not univocally detected: While van Huylenbroeck et al. [12] showed that open spaces have a high positive influence on rental prices of agritourism operations, Waltert and Schläpfer [8] identified only a modest effect. The latter, however, focused on housing prices in rural areas.

As mentioned before, the purpose of this study is to enhance clarity on the contribution of farming activities on the attractiveness of the agritourism sector and to this aim, we developed a hedonic pricing model to detect to which extent the type of activities offered by farm operators in the studied region influences prices of tourist accommodations.

\section{Methodology}

\subsection{Case Selected: Southern Tyrolean Agritourism Operations}

The study area is South Tyrol, which belongs to the Italian region of Trentino Alto-Adige set on the Alps (Figure 1). South Tyrol is close to the Austrian border and counts two ethnic minorities: The German speaking and the Ladin speaking minority. The alpine setting hosts a varied agricultural 
structure. Out of the 17,133 individual farms, the ones producing wine and fruits—especially apple-are set mainly on the plain, while dairy farming is concentrated in the higher regions. The area used for agricultural purposes in South Tyrol amounts to 267,000 hectares (660,000 acres), corresponding to 36\% of South Tyrol's total area. This expanse consists, for the most part, of meadows, grazing land and arable land $(90 \%)$, orchards $(7 \%)$, vineyards $(2 \%)$, and other $(1 \%)$. In the summertime, South Tyrol is a hallmark for hiking and biking tourism as well as for food and wine tourism and for cultural and rural tourism.

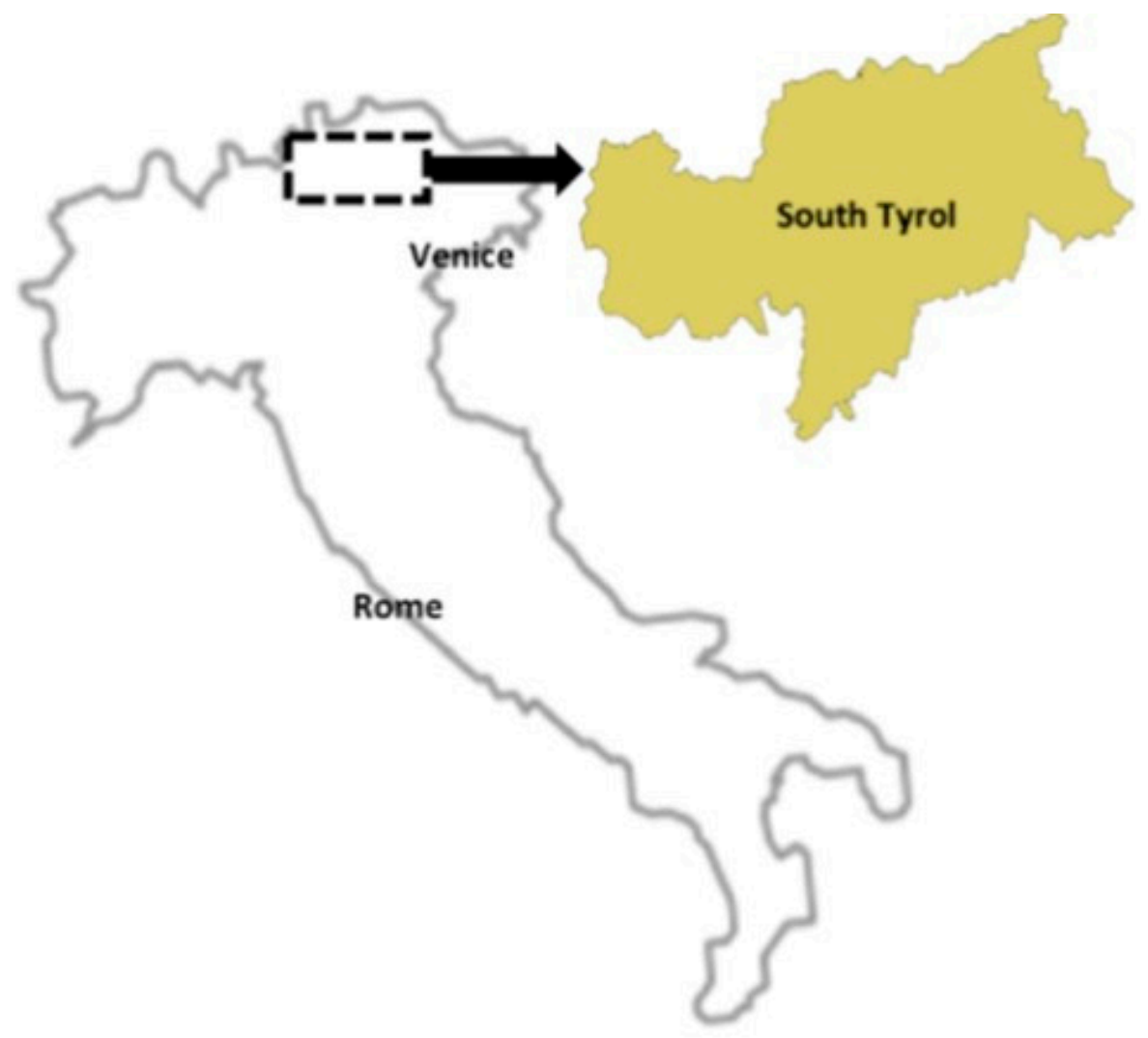

Figure 1. South Tyol (Italy). Own sources.

Many farmers have diversified their farming activities in farm tourism, although this sector has some peculiarities respect to the rest of Italy. For instance, outside South Tyrol, farm tourism operators belong to Anagritur, the main agritourism consortium, which groups the three associations Agriturist, Terranostra, and Turismo Verde, all backed by the national agricultural association (Confindustria, Coldiretti, and Confederazione Italiana Agricoltori, respectively). On the contrary, in South Tyrol, most farmers belong to the Red Rooster Association, which is controlled by the South Tyrolean Association of Farmers (Südtiroler Bauernbund) and which embraces, above all, farmers belonging to the German speaking minority.

As in the rest of Italy, South Tyrolean agritourism operators are also obliged to follow the principles of the national legislation on agritourism, which encompasses both rights and obligations. Specifically, farmers who offer hospitality or catering to agritourists are allowed to label their business as agritourism only if their hospitality-related activity is connected to the agricultural one. Practically, the legislator imposes that agritourism is exercised only by a farm in activity. Furthermore, the agritourism-related activities cannot prevail over normal agricultural activities. If the aforementioned requisites are respected, then agritourism operators enjoy a special fiscal regime. 


\subsection{Methods of Hedonic Prices and Data Collection}

The theory of hedonic pricing is attributed to Lancaster's consumption theory [14] and Rosen [15]. It has been used widely for different pricing environments since it enables estimating the implicit prices for characteristics of a good or service given a valid purchase or sale price. Apart from the estimation of implicit prices for agricultural and food products (particularly wine), the method has also been used in environmental economics since it allows to study pricing for market and non-market goods that differ in specific environmental characteristics. In tourism, the method is used by many authors to characterize hotel and accommodation prices (e.g., [16-18]). In the literature on rural tourism, van Huylenbroeck et al. [12] used it to demonstrate how positive externalities of agriculture boost rural tourism.

The dataset we analyzed was obtained from the South Tyrolean Farmers Association. It reports information for about 2200 Red Rooster holiday farms in South Tyrol, and records accommodation prices and farm accommodation attributes or characteristics for the 2016 season. Concerning the specific farm accommodation/destination attributes to be employed as independent variables, we were able to discern both qualitative and quantitative variables. The dataset contains a long list of potential explanatory variables with information whether the farm accommodation is open all year around, if it has internet access, barrier-free access, a balcony or terrace, a wellness area/sauna or a specific interior design (e.g., wooden floors), if English is spoken, if the farm is organic, if it engages in berry cultivation, livestock farming, wine production, fruit or vegetable growing, if there is an additional living room or outdoor area available for leisure activities (e.g., BBQ), if there is a children's playground or a storage room for leisure equipment (e.g., skies) on the farm, if the option to have non-smoking rooms exists, as well as whether options to book full/half board or an optional breakfast exist. Moreover, we have information on the location of the farm, i.e., the altitude above sea level as well as the distance of the farm to various points of interest including the next swimming lake, the town or city center, the next bus stop or train station, the next cross-country trail, the next bike-path, the next sled-run, and the next skiing slope.

Reported prices for a farm holiday differentiate peak and low season stays. Accommodation quality is rated using a five-flower scheme (i.e., somewhat analogous to common hotel ratings). The average farm in our sample has a rating of 3 flowers. In addition to the impact of accommodation quality on prices, we are particularly interested in analyzing the quality of food services offered. However, only 15 farms in our sample offer any meals apart from breakfast. Hence, we restrict our hedonic analysis to those farms offering accommodation and breakfast. Typically, a farm breakfast is offered as an optional service and in our sample, it has an average additional cost of $9.40 €$ per person, varying between 4 and $20 €$. This restriction reduces the usable sample size for our empirical model to 367 farms. The additional price for the breakfast option is taken as a measure to assess the quality of food services offered. In this context, we refer to the literature that prices are an indicative signal of quality (e.g., [19-21]).

Almost $90 \%$ of the farms remain open for their guests all year round and about $62 \%$ of operators are proficient in English. Typically, a holiday farm is relatively close to a town center, with an average distance of about two kilometers. On average, the agritourism farms are located at about 900 meters above sea level and engage in multiple farming activities: $64 \%$ are livestock or dairy operations, $36 \%$ are fruit farms (mainly apples), $25 \%$ engage in wine-growing, $6 \%$ grow vegetables, and about $3 \%$ grow berries. Only about $5.5 \%$ of the farms in the sample are organic. The average price for a guest room on a holiday farm in South Tyrol is $88.34 €$ per night in the main and $57.41 €$ per night in the low season. Note that recorded prices are adjusted to accommodate up to two persons per night. 
The dependent variable used in the analysis is the rental price of a guest room per night. We ran two models referring to the spring and summertime-one for the peak (June to September) and one for the low season (April and May)—using the open-source software package Gretl. In both analyses, the peak and the low season prices were transformed into the natural logarithm of the price. Since no agricultural activity takes place in winter, we concentrated our analyses to the period April to September, which are also intensive periods for the farming activities. The following equation represents the general hedonic model as applied in the empirical study:

$$
\ln P_{i}=\alpha+\beta_{1} z_{1 i}+\beta_{2} z_{2 i}+\ldots+\beta_{k} z_{k i}+u_{i}
$$

where $P_{i}$ are the accommodation prices per night covering up to two persons, the coefficients $\beta_{k}$ report implicit prices for specific farm accommodation/destination attributes, which are denoted by $z_{k}$ and included in the estimated models presented below. As for the results, we will only report those variables that have a significant impact on the price of the farm accommodation.

\section{Results}

In this section, we first present the results of the estimated hedonic model for the peak season prices reported, followed by those related to low season prices. The Ramsey's RESET test indicates that the specified linear functional form is correct for both models with the test being executed adding squared and cubed residuals. The F-test statistic was insignificant at the $10 \%$ level for both models with $\mathrm{F}=1.1882(p=0.306)$ for the peak season and $\mathrm{F}=2.2093(p=0.112)$ for the low season. Table 1 reports the estimation results including standard errors and $t$-values for the first model listing only those explaining variables that are significant. In terms of adjusted $R^{2}$, the models' explanatory power is good, as the value is around $30 \%$. Variables that significantly affect the accommodation price during the peak season are the accommodation quality rating (flowers) and the quality of food services as reported by breakfast prices, the availability of a wellness area/sauna, the practice of fruit growing or livestock farming (animal husbandry) on the farm, whether the operation is open all year round, as well as the presence of a living room. Other characteristics such as internet access, a balcony and terrace, or the distance to the city or town center are not significant and thus are not reported in Table 1.

We stress that the flower-rating is the most significant variable affecting peak season accommodation prices during the summer peak and low seasons. An additional flower would add about $14 \%$ to the predicted rate for a one-night stay. Moreover, the quality of food services as reported by breakfast prices is another important variable affecting the willingness to pay for a farm stay. Given its functional (log-log) representation in the model, the estimated coefficient suggests that at average prices, a $1 \%$ increase in the breakfast price has the potential to raise the accommodation price by $0.23 \%$. While this seems low at first, recall that the average peak season accommodation price is about $88 €$ while the average breakfast price is only $9.40 €$. As mentioned, fruit-growing and animal husbandry are variables able to decrease guests' willingness to pay for an accommodation on a holiday farm in South Tyrol. If the operation practices either fruit growing or is a livestock operation, the estimated model suggest that the accommodation rates decrease by $14 \%$ and $1 \% 9$, respectively. These findings confirm previous studies [12,13].

A detailed view of the accommodation attributes reveals other interesting aspects. For instance, the existence of a living room is negatively related to the price. The reason might be that most guests may not require a common living room during the peak season as there are plenty of outdoor activities to undertake. Furthermore, English spoken would raise the accommodation prices by about $6 \%$ and a wellness area or sauna by about $14 \%$. If a farm is "open all year" for its guest, the estimated price effect is also significant and equal to about $14 \%$ (other things equal). 
Table 1. Influence of selected variables on summer peak season prices. Dependent variable: Ln (Price Peak Season).

\begin{tabular}{cccccc}
\hline & Coefficient & Std. Error & t-Ratio & p-Value & Sig. \\
\hline Constant & 3.542 & 0.1525 & 23.22 & $<0.0001$ & $* * *$ \\
Flower Rating & 0.143 & 0.0223 & 6.400 & $<0.0001$ & $* * *$ \\
Food/Breakfast Quality & 0.229 & 0.0706 & 3.238 & 0.0013 & $* * *$ \\
Open all year & 0.138 & 0.0589 & 2.349 & 0.0194 & $* *$ \\
English spoken & 0.063 & 0.0330 & 1.904 & 0.0577 & $*$ \\
Separate Living Room & -0.077 & 0.0325 & -2.352 & 0.0192 & $* *$ \\
Wellness Area & 0.139 & 0.0502 & 2.776 & 0.0058 & $* * *$ \\
Fruit Growing Farm & -0.144 & 0.0662 & -2.174 & 0.0304 & $* *$ \\
Livestock Farm & -0.196 & 0.0667 & -2.939 & 0.0035 & $* * *$ \\
\hline
\end{tabular}

Note: Own estimation $\left(n=353\right.$, adj. $\left.\mathrm{R}^{2}=0.304\right)$. Prices are per room/night. ${ }^{* * *}, * *$, and ${ }^{*}$ indicate significance at the $1 \%, 5 \%$, and $10 \%$ level, respectively.

Table 2 displays the results of the hedonic price model for the low season. The adjusted $\mathrm{R}^{2}-\mathrm{or}$ the models' explanatory power-reaches almost the value of $43 \%$. As for the previous model, the flower rating system displays a positive and significant impact on the price of the accommodation. In addition, the breakfast price displays again a positive and significant impact on the accommodation price. In this case, if the price for the breakfast increases by $1 \%$, the estimated price for an accommodation rises by $0.16 \%$. Recall that the average low season accommodation rate is about $57.4 €$ while the average breakfast price is $9.40 €$. Although the food service effect is higher in the peak season, it still translates into a significant increase in the willingness to pay for a farm stay. Other significant variables for the low season are internet access, the presence of a children's playground, the distance to the next swimming area, the distance to the next city center, as well as two farm typologies, namely the wine production and the organic farming. In the following, these findings are discussed in detail.

Compared with the previous model, some characteristics appear to be particularly important for the determination of the lodging price during the low season due to a different typology of agritourism guests. For farms offering a children's playground, the model suggests that the estimated accommodation price would decrease by $3.8 \%$, holding all other variables constant. This fact may be explained as follows: During the lower season, guests might come without children, as they are attending school; hence there is no need for a children's playground.

The flower rating is, again, highly significant, meaning that the predicted accommodation rate increases on average by about $14 \%$ for another flower (e.g., for a change from a three-flower farm to a four-flower farm). Moreover, the quality of food services as reported by breakfast prices is also important during the low season significantly affecting the willingness to pay for a farm stay, although slightly lower than during the peak season. The distances to the next city or town center is positively related to accommodation prices, i.e., farm stay guest seem to value distance away from a town center as desirable (e.g., being quieter, more relaxing). The estimated effect is $2 \%$ per $\mathrm{km}$. Two other attributes significant during the low season but not during the summer peak season are internet access (which may be less important for peak season guests given many summer attractions) and distance to an outdoor attraction like a swimming lake (which may be crowed during the peak season and thus not carry a significant price premium).

Concerning agricultural externalities, the findings indicate that if the holiday farm supplies wine or organic farming, the predicted accommodation price will increase. Hence, a winery operation and organic farming may provide positive external effects for farm stay operations, while fruit farms and livestock operations may imply negative external effects at least during the peak season. 
Table 2. Influence of selected variables on summer low season prices.

\begin{tabular}{cccccc}
\hline & Coefficient & Std. Error & t-Ratio & p-Value & Sig. \\
\hline Constant & 3.190 & 0.115 & 27.82 & $<0.0001$ & $* * *$ \\
Flower Rating & 0.142 & 0.0179 & 7.935 & $<0.0001$ & $* * *$ \\
Log (Price Breakfast) & 0.162 & 0.0552 & 2.941 & 0.0036 & $* * *$ \\
Child Playground & -0.088 & 0.0408 & -2.148 & 0.0327 & $* *$ \\
Internet access (WLAN) & 0.049 & 0.0251 & 1.940 & 0.0535 & $*$ \\
Organic Farm & 0.135 & 0.0553 & 2.442 & 0.0154 & $* *$ \\
Wine Growing Farm & 0.139 & 0.0274 & 5.088 & $<0.0001$ & $* * *$ \\
Distance City Center & 0.025 & 0.0059 & 4.223 & $<0.0001$ & $* *$ \\
Distance Swim Lake & 0.0017 & 0.00091 & 1.911 & 0.0573 & $*$ \\
\hline
\end{tabular}

Note: Own estimation $\left(n=245\right.$, adj. $\left.\mathrm{R}^{2}=0.428\right)$. Prices are per room/night. ${ }^{* * *},{ }^{* *}$, and ${ }^{*}$ indicate significance at the $1 \%, 5 \%$, and $10 \%$ level, respectively.

\section{Discussion and Conclusions}

Based on a hedonic analysis, this study presents a number of farm attributes, which may significantly affect accommodation rates for a farm stays in South Tyrol, the German-speaking region of northern Italy.

The dataset was obtained from the "Südtiroler Bauernbund" and analyzed 367 Red Rooster holiday farms in South Tyrol that include food services (i.e., the option to have breakfast). On the basis of these data, two models were estimated referring to the high and low seasons around the spring and summertime. Concerning the intrinsic accommodation characteristics embraced in the study, these are of varied nature: Some relate to the quality and comfort of the accommodation, as in the case of the "flower" rating, others to the geographic location of the operation (e.g., distance from the city center) and to positive or negative externalities related to agricultural production. The latter were included to understand whether guests "value or despise" agricultural activities. Referring to the accommodation quality attributes, results show that some of the attributes were thoroughly significant in determining accommodation prices. Especially the variables "flower rating" and "quality of food services" (as reported by breakfast prices) were highly significant and prove to be important factors determining farm stay accommodation rates. In addition to quality upgrades (i.e., obtaining more flowers), additional service offers such as the option to have breakfast, seem to have a positive impact on accommodation prices.

Concerning agricultural externalities, our findings show that farming practices do affect farm tourism, although not always in a positive manner. For instance, accommodation prices appear to be negatively influenced by the presence of fruit growing and intensive livestock. In the western part of South Tyrol, the main fruit crop is intensive apple production, and it seems to have a negative influence on farm tourists. Similarly, the presence of intensive livestock activities has a negative impact on accommodation rates, probably because guests associate it with negative effects such as air pollution and diminished attractiveness of the landscapes. On the other side, farming practices such as wine production and organic farming have a positive influence on rental prices. Although wine production is an intensive agricultural activity likewise the apple production, it is not negatively regarded by farm tourists, maybe because wine landscapes belong to the collective imaginary of an idealized agriculture or, as stated by Mitchell, Charters, and Albrecht [22] of a local mythology of rurality. On the other side, the positive returns of organic farming on rental prices can be explained by the fact that most farm tourists in South Tyrol come from German-speaking countries, where the demand for organic products is relatively high. Thus, as stated by Quan and Wang [23], "although tourists seek various and novel experiences, they often 'bring' their habits and preferences formed at home with them" (p. 301). 


\section{Implications and Future Research}

The negative impact of monocultural agriculture and intensive breeding on the one hand and the positive effect of organic farming on the other hand show that a change of course in agriculture in favor of more environmental and social sustainability pays back the farmers not only in their role as agricultural entrepreneurs, but also as managers of agritourism activities. As a matter of fact, in the area studied, the legislator is urging more and more farmers to convert their land into organic or, at least, more extensive agriculture.

Concerning future extensions of this research, it could be interesting to extend the current study to a larger region, as farm holidays are not only offered in South Tyrol, but also in other European countries. As mentioned above, the Red Rooster label is a special quality seal for holiday farms in this region. An enlargement of the present analysis would lead to more detailed results. Future studies could also investigate the demand side. A suggestion might be to do a survey among frequent guests or among people that are interested in experiencing farm holidays in South Tyrol or another Italian region.

Of course, the study may suffer from limitations. For example, the hedonic regression model may not consider other factors which have an impact on the tourists' willingness to pay for farm accommodation (e.g., room size, easy access to public transport). Another weakness of the study might be the fact that it relies on data provided by farm operators who have to correctly report the information to the Red Rooster brand. For example, if the owner of a holiday farm has not specified the existence of non-smoking rooms or breakfast options, the results of the study might be biased. Also, as stated by [12], such an approach does not exclude the possibility that the prices declared differ from the real prices paid because of special offers.

Notwithstanding this, our research confirms the fact that alpine tourism is a sector still in evolution, showing that agricultural externalities could become an important issue for farm guests in the future, since the number of environmentally aware tourists in the mountain setting is steadily increasing [24,25]. This work serves as a starting point for research. All in all, further studies are called in order to study the liminal frontier between agriculture and tourism in the agritourism sector.

Author Contributions: All three authors conceived and designed the article; K.L.S. is responsible for the introduction, study case, and conclusion; A.S. contributed to the overall structure of the study and conducted a case study; G.S. is responsible for the overall conception and the data analysis.

Funding: Günter Schamel acknowledges the support from a research grant of the Free University of Bozen-Bolzano with the project title: Local Residents and Demand for Quality Tourism. The authors are covering the costs to publish in open access.

Conflicts of Interest: The authors declare no conflict of interest. The funding sponsors had no role in the design of the study; in the collection, analyses, or interpretation of data; in the writing of the manuscript, and in the decision to publish the results.

\section{Abbreviations}

The following abbreviations are used in this manuscript:

CAP Common Agricultural Policy

\section{References}

1. Hjalager, A.M. Agricultural diversification into tourism: Evidence of a European Community development programme. Tour. Manag. 1996, 17, 103-111. [CrossRef]

2. Yoon, Y.S.; Han, S.H.; Kim, Y.L. A Study of Segmentation of Foreign Rural Tourists based on Rural Tourism Attributes, and Satisfaction and Loyalty. J. Korean Soc. Rural Plan. 2014, 20, 115-126. [CrossRef]

3. Knowd, I. Tourism as a mechanism for farm survival. J. Sustain. Tour. 2006, 14, 24-42. [CrossRef]

4. Embacher, H. Marketing for agritourism in Austria: Strategy and realization in a highly developed tourist destination. J. Tour. Res. 1994, 2, 61-76.

5. Wood, E.H.; Thomas, R. Festivals and tourism in rural economies. In International Perspectives of Festivals and Events: Paradigms of Analysis; Elsevier: London, UK, 2008; pp. 149-158. 
6. Urry, J. The Tourist Gaze; Sage: London, UK, 2002.

7. Howley, P.; Donoghue, C.O.; Hynes, S. Exploring public preferences for traditional farming landscapes. Landsc. Urban Plan. 2012, 104, 66-74. [CrossRef]

8. Waltert, F.; Schläpfer, F. Landscape amenities and local development: A review of migration, regional economic and hedonic pricing studies. Ecol. Econ. 2010, 70, 141-152. [CrossRef]

9. Judson, D.H.; Reynolds-Scanlon, S.; Popoff, C.L. Migrants to Oregon in the 1990's Working Age, Near-Retirees, and Retirees Make Different Destination Choices. Rural Am./Rural Dev. Perspect. 1999, 14, $24-31$.

10. Beyers, W.B.; Lindahl, D.P. Lone eagles and high fliers in rural producer services. Rural Dev. Perspect. 1996, 11, 2-10.

11. Deller, S.C.; Tsai, T.H.; Marcouiller, D.W.; English, D.B. The role of amenities and quality of life in rural economic growth. Am. J. Agric. Econ. 2001, 83, 352-365. [CrossRef]

12. Van Huylenbroeck, G.; Vanslembrouck, I.; Calus, M.; Van de Velde, L. Synergies between farming and rural tourism: Evidence from Flanders. EuroChoices 2006, 5, 14-21. [CrossRef]

13. Sidali, K.L. Farm tourism: A cross-country empirical study in Germany and Italy. Ph.D. Thesis, Almamater Studiorum University of Bologna, Bologna, Italy, 2009.

14. Lancaster, K.J. A new approach to consumer theory. J. Polit. Econ. 1966, 74, 132-157. [CrossRef]

15. Rosen, S. Hedonic prices and implicit markets: Product differentiation in pure competition. J. Polit. Econ. 1974, 82, 34-55. [CrossRef]

16. Chen, C.F.; Rothschild, R. An application of hedonic pricing analysis to the case of hotel rooms in Taipei. Tour. Econ. 2010, 16, 685-694. [CrossRef]

17. Thrane, C. Hedonic price models and sun-and-beach package tours: The Norwegian case. J. Travel Res. 2005, 43, 302-308. [CrossRef]

18. Schamel, G. Weekend vs. midweek stays: Modelling hotel room rates in a small market. Int. J. Hosp. Manag. 2012, 31, 1113-1118. [CrossRef]

19. Nelson, P. Advertising as information. J. Polit. Econ. 1974, 82, 729-754. [CrossRef]

20. Milgrom, P.; Roberts, J. Price and advertising signals of product quality. J. Polit. Econ. 1986, 94, 796-821. [CrossRef]

21. Bagwell, K.; Riordan, M.H. High and declining prices signal product quality. Am. Econ. Rev. 1991, 81, $224-239$.

22. Mitchell, R.; Charters, S.; Albrecht, J.N. Cultural systems and the wine tourism product. Ann. Tour. Res. 2012, 39, 311-335. [CrossRef]

23. Quan, S.; Wang, N. Towards a structural model of the tourist experience: An illustration from food experiences in tourism. Tour. Manag. 2004, 25, 297-305. [CrossRef]

24. Sidali, K.; Huber, D.; Schamel, G. Long-term sustainable development of tourism in South Tyrol: An analysis of tourists' perception. Sustainability 2017, 9, 1791. [CrossRef]

25. Gatti, S. Wine Economics and its External Effects: The case of Wine Tourism; Wine in the Old World, New Risks and Opportunities; FrancoAngeli: Milan, Italy, 2003.

(C) 2019 by the authors. Licensee MDPI, Basel, Switzerland. This article is an open access article distributed under the terms and conditions of the Creative Commons Attribution (CC BY) license (http://creativecommons.org/licenses/by/4.0/). 